\title{
Penerapan Aplikasi Simulasi Electronic Workbench dan Proteus pada Materi Penerapan Rangkaian Elektronika bagi Siswa Kelas XI Teknik Elektronika Industri
}

\author{
Siti Nurhidayah ${ }^{1}$, Didik Aribowo $^{2}$, Desmira $^{3}$ \\ 1,2,3 Magister Program Studi Pendidikan Vokasional Teknik Elektro Fakultas Keguruan dan Ilmu Pendidikan, Universitas \\ Sultan Ageng Tirtayasa, Indonesia. \\ ${ }^{1}$ sitinurhidayah479@gmail.com* \\ *corresponding author
}

\begin{abstract}
The purpose of this research was to determine student learning outcomes after the application of EWB software learning media during the learning process in the subject of applying electronic circuits; knowing student learning outcomes after the application of proteus software learning media during the learning process in the subject of applying electronic circuits; knowing the difference in student learning outcomes after the application of EWB and proteus software learning media in the subject of implementing electronic circuits.

This type of research is an experiment with experimental research method (experimental) and pretest-posttest control group design. The population in this study were students of class XI SMKN 1 Cikande majoring in Industrial Electronics Engineering which consisting of 38 students. The research sample consisted of 2 classes with a total of 21 students and 17 students. The sampling technique used in this research is saturated sampling technique. Data collection instruments used were is pretest and posttest and psychomotor observation sheets. Data analysis technique used the Mann Withney test (U-test) to test the hypothesis with SPSS version 21.0 .

The results of this study suggests that (1) there are differences in learning outcomes in cognitive aspects between students treated with EWB and proteus. The average student learning outcomes in the cognitive aspects of the proteus were 73.23, greater than the average student learning outcomes in the cognitive aspects of the EWB, which was 68.1. Uji-U calculations obtained sig. (2-tailed) of 0,000. If the value is sig. (2-tailed) is less than alpha 0.05, then the $H_{0}$ statement is rejected and $H_{1}$ is accepted. (2) there are differences in psychomotor learning outcomes between students treated with proteus and EWB. The average student learning outcomes of the psychomotor aspects treated with the proteus were 82.06, greater than the average learning outcomes of students in the psychomotor aspects treated with the EWB, namely 75.48. Uji-U calculations obtained sig. (2-tailed) of 0,000. If the value is sig. (2-tailed) less than alpha 0.05, then the $H_{0}$ statement is rejected and $H_{1}$ is accepted.
\end{abstract} Article Info

\footnotetext{
ABSTRAK

Tujuan penelitian ini adalah mengetahui hasil belajar siswa setelah diterapkan media pembelajaran software EWB dalam mata pelajaran penerapan rangkaian elektronika; mengetahui hasil belajar siswa setelah diterapkan media pembelajaran software proteus dalam mata pelajaran penerapan rangkaian elektronika;
} 
mengetahui perbedaan hasil belajar siswa setelah diterapkan media pembelajaran software EWB dan proteus dalam mata pelajaran penerapan rangkaian elektronika. Jenis penelitian yang digunakan yaitu eksperimen dengan metode penelitian eksperimen (eksperimental) dan desain pretest-posttest control group design. Populasi dalam penelitian ini adalah siswa kelas XI SMKN 1 Cikande jurusan Teknik Elektronika Industri yang terdiri dari 38 siswa. Sampel penelitian terdiri dari 2 kelas dengan total 21 siswa dan 17 siswa. Teknik pengambilan sampel yang digunakan dalam penelitian ini teknik sampling jenuh. Instrumen pengumpulan data yang digunakan adalah pretest, posttest dan lembar observasi psikomotor. Teknik analisis data menggunakan uji Mann Withney (Uji-U) untuk menguji hipotesis dengan SPSS versi 21.0

Hasil penelitian ini menunjukkan bahwa (1) ada perbedaan dalam hasil belajar aspek kognitif antara siswa yang diperlakukan dengan EWB dan proteus. Rata-rata hasil belajar siswa aspek kognitif proteus sebesar 73,23 lebih besar dibandingkan rata-rata hasil belajar siswa pada aspek kognitif EWB yaitu sebesar 68,1. Perhitungan Uji-U diperoleh hasil sig. (2-tailed) sebesar 0,000. Jika nilai sig. (2tailed) kurang dari alpha 0,05, maka pernyataan H0 ditolak dan H1 diterima. (2) ada perbedaan hasil belajar ranah psikomotor antara siswa yang diberi perlakuan dengan proteus dan EWB. Rata-rata hasil belajar siswa aspek psikomotor yang diberi perlakuan proteus sebesar 82,06 lebih besar dibanding dengan rata-rata hasil belajar siswa aspek psikomotor yang diberi perlakuan EWB yaitu sebesar 75,48. Perhitungan Uji-U diperoleh hasil sig. (2-tailed) sebesar 0,000. Jika nilai sig. (2tailed) kurang dari alpha 0,05, maka pernyataan $\mathrm{H} 0$ ditolak dan $\mathrm{H} 1$ diterima.

\section{PENDAHULUAN}

Sekolah Menengah Kejuruan (SMK) merupakan pendidikan formal yang banyak diminati karena proses pembelajarannya memberikan pelatihan diberbagai bidang keahlian. Menurut Undang-undang No. 20 Tahun 2003 pasal 15, menyatakan bahwa pendidikan kejuruan adalah pendidikan menengah yang mengutamakan perkembangan kemampuan peserta didik dalam melaksanakan jenis pekerjaan tertentu. SMK memiliki peranan yang sangat penting dalam upaya meningkatkan sumber daya manusia yang mampu memiliki keterampilan yang terdidik dan diperlukan dalam dunia kerja. Tujuan tersebut dapat tercapai melalui proses belajar mengajar yang diatur oleh pendidik yang mana pada proses tersebut terdapat interaksi antara peserta didik dengan lingkungan belajarnya.

Dalam proses belajar mengajar dibutuhkan metode yang efektif agar siswa dapat memahami materi dengan baik sehingga akan tercapailah nilai Kriteria Ketuntasan Minimum (KKM). Salah satu metode yang digunakan untuk menyampaikan materi pembelajaran dengan baik yaitu dengan menggunakan media pembelajaran. Penggunaan media pembelajaran tidak hanya digunakan untuk menyampaikan materi dengan baik, tetapi juga dapat meningkatkan semangat belajar siswa dalam belajar. Media pembelajaran yang dapat digunakan bermacam-macam, salah satunya adalah media komputer. Media komputer dalam pembelajaran yaitu media yang menggunakan teknologi berbasis komputer dengan cara menghasilkan atau menyampaikan materi dengan menggunakan sumber-sumber yang berbasis sistem digital.

Penggunaan media komputer dalam proses pembelajaran dirancang untuk dapat memotivasi siswa dan meningkatkan pengetahuan serta keterampilannya. Dengan adanya media komputer dalam proses belajar mengajar dikelas, dapat memecahkan masalah pembelajaran yakni mengubah pola pembelajaran siswa menuju lebih efektif dengan meningkatnya pengetahuan dan keterampilan serta dapat menambah motivasi siswa yang pada akhirnya juga dapat meningkatkan nilai belajar siswa.

Berdasarkan hasil wawancara yang dilakukan bersama guru pengampu mata pelajaran Penerapan Rangkaian Elektronika di SMKN 1 Cikande jurusan Teknik Elektronika Industri (TEI) ditemukan beberapa permasalahan selama proses pembelajaran. Menurut penuturan dari bapak Edi selaku guru pengampu mata pelajaran Penerapan Rangkaian Elektronika, ketika dilakukan wawancara 
menuturkan bahwa proses pembelajaran untuk mata pelajaran tersebut belum sepenuhnya dilaksanakan secara maksimal. Hal ini disebabkan karena kurangnya pemanfaatan media pembelajaran, sehingga siswa masih mengalami kesulitan dalam memahami materi yang disampaikan, meskipun pada saat proses pembelajaran sudah menggunakan buku yang dijadikan sebagai sumber bahan pembelajaran. Hal ini dapat dilihat dari hasil belajar peserta didik yang memenuhi kriteria KKM pada mata pelajaran penerapan rangkaian elektronika adalah sebesar $30 \%$.

Menurut hasil observasi, hal itu dikarenakan kurangnya pemanfaatan penggunaan media pembelajaran. Karena hasil dari angket yang disebar menunjukan bahwa $62,5 \%$ media yang sering digunakan hanyalah power point (PPT), prosentase tersebut sama halnya dengan metode pembelajaran yang sering digunakan yaitu metode ceramah. Untuk meningkatkan keterampilan dan hasil proses pembelajaran siswa, salah satu media pembelajaran yang dapat digunakan adalah software simulasi Electronic Work Bench (EWB) dan proteus yang dapat dijadikan media dalam mendesain rangkaian dasar logika dan digital saat akan memulai praktikum, karena menurut observasi $68,4 \%$ peserta didik belum pernah menggunakan software simulasi Electronic Work Bench (EWB) maupun proteus.

Penelitian ini dikaji dengan penelitian relevan yang memiliki tema yang berkaitan dengan beberapa penelitian sebelumnya. Hal ini guna menjadi acuan agar tehindar dari dupikasi penelitian, diantaranya:

Pertama, Pengaruh Media Pembelajaran Software Proteus Pada Mata Pelajaran Penerapan Rangkaian Elektronika Terhadap Hasil Belajar Siswa Kelas XI Teknik Audio Video Di SMK Negeri 3 Surabaya oleh Miftahul Mukminin dan Agus Budi Santosa (2016:147-154). Hasil dari penelitian tersebut adalah terdapat pengaruh positif atau peningkatan terhadap hasil belajar siswa yang dibelajarkan menggunakan model pembelajaran langsung menggunakan software proteus 8 profesional pada mata pelajaran penerapan rangkaian elektronika, serta aktivitas belajar siswa pada model pembelajaran langsung menggunakan software proteus 8 profesional lebih baik daripada aktivitas belajar siswa dalam model pembelajaran langsung tanpa software proteus 8 profesional.

Terakhir Pengaruh Penggunaan Media Pembelajaran Electronic Workbench (EWB) Dan Proteus Terhadap Pencapaian Kompetensi Pada Mata Pelajaran Teknik Elektronika Dasar Siswa Kelas X Teknik Elektronika Industri SMK N 2 Pengasih oleh Rasyid Nugroho (2014). Hasil dari penelitian ini adalah diketahui bahwa terdapat perbedaan peningkatan hasil belajar siswa pada mata pelajaran teknik elektronika antara siswa yang mendapat perlakukan media pembelajaran software aplikasi Electronic Workbench (EWB) dengan siswa yang mendapat perlakuan media pembelajaran software aplikasi proteus. Peningkatan hasil belajar siswa pada mata pelajaran teknik elektronika dengan menggunakan media pembelajaran software aplikasi electronic workbench (EWB) lebih tinggi dibanding dengan menggunakan media pembelajaran software aplikasi proteus.

Berdasarkan referensi diatas dapat ditarik kesimpulan bahwa penelitian sebelumnya hanya berfokus pada aspek hasil belajar siswa atau aspek kognitif. Dan itu menjadi pembeda dalam penelitian penelitian ini, karena pada penelitian ini tidak hanya berfokus pada aspek kognitif namun juga pada aspek psikomotor

\section{METODE}

Metode yang digunakan pada penelitian ini adalah metode kuasi eksperimen. Metode kuasi eksperimen dapat diartikan sebagai metode penelitian yang digunakan untuk mencari pengaruh perlakuan terhadap yang lain dalam kondisi yang terkendalikan (Sugiyono, 2015). Penelitian eksperimental yaitu penelitian yang digunakan untuk menemukan pengaruh variabel tertentu dengan variabel lain pada kondisi yang terkendali. Penelitian ini bertujuan untuk menguji hipotesis dengan desain penelitian dimana kedua kelas sampel diberi perlakuan yang berbeda. Di kelas sampel pertama, siswa belajar menggunakan software EWB dan pada kelas sampel kedua, siswa belajar menggunakan software Proteus.

Desain penelitian yang digunakan adalah pretest-posttest control group design (Arikunto, 
2014) dimana kedua kelompok yang akan diberi prestest untuk mengetahui kondisi awal apakah ada perbedaan antara kedua kelompok dan kemudian diberi posttest untuk mengetahui hasil dari kedua kelompok setelah diberi perlakuan. Dalam desain ini kedua kelompok sampel tidak dipilih secara acak. Adapun bentuk desain penelitian pretest-posttest control group design terdapat pada Table 1.

Tabel 1. Desain penelitian

\begin{tabular}{lcccc}
\hline Kelompok & $\begin{array}{c}\text { Pre } \\
\text { test }\end{array}$ & Perlakuan & $\begin{array}{c}\text { Post } \\
\text { test }\end{array}$ & $\begin{array}{c}\text { Pening } \\
\text { katan }\end{array}$ \\
\hline Kontrol & $\mathrm{O}_{1}$ & $\mathrm{X}_{1}$ & $\mathrm{O}_{2}$ & $\mathrm{O}_{2}-\mathrm{O}_{1}$ \\
Eksperimen & $\mathrm{O}_{3}$ & $\mathrm{X}_{2}$ & $\mathrm{O}_{4}$ & $\mathrm{O}_{4}-\mathrm{O}_{3}$ \\
\hline
\end{tabular}

Keterangan:

$\mathrm{O}_{1}$ : Pretest Kelompok kontrol

$\mathrm{O}_{2}$ : Posttest Kelompok kontrol

$\mathrm{O}_{3}$ : Pretest Kelompok eksperimen

$\mathrm{O}_{4}$ : Posttest Kelompok eksperimen

$\mathrm{X}_{1}$ : Pembelajaran dengan software EWB

$\mathrm{X}_{2}$ : Pembelajaran dengan software Proteus

Penelitian ini dilaksanakan di SMKN 1 Cikande pada bulan November 2019. Teknik pegambilan sampel dilakukan dengan sampling jenuh, yaitu semua anggota populasi digunakan sebagai sampel (Sugiyono, 2015:85). Populasi dalampenelitian ini berjumlah 38 orang, dengan sampel kelas XI TEI A sebagai kelas control dan kelas XI TEI B sebagai kelas eksperimen.

Tabel 2. Populasi dan sampel

\begin{tabular}{cccl}
\hline \multirow{2}{*}{ Kelas } & \multicolumn{2}{c}{ Subjek Penelitian } & \multirow{2}{*}{ Keterangan } \\
\cline { 2 - 3 } & Populasi & Sampel & \\
\hline XI TEI A & 21 & 21 & EWB \\
XI TEI B & 17 & 17 & Proteus \\
\hline
\end{tabular}

Teknik pengumpulan data yang digunakan dalam penelitian ini adalah (1) Observasi, observasi ini peneliti lakukan di kelas XI TEI SMKN 1 Cikande dengan mengamati langsung kegiatan pembelajaran di kelas yang dilakukan oleh guru, (2) Wawancara, wawancara dilakukan oleh peneliti kepada guru pengampu mata pelajaran penerapan rangkaian elektronika sebagai studi pendahuluan untuk mengetahui permasalahan yang terjadi selama proses pembelajaran mata pelajaran penerapaian rangkaian elektronika, (3) Dokumentasi, Dokumentasi merupakan cara yang digunakan untuk membuktikan adanya penelitian, baik data nilai, surat-surat serta foto atau gambar selama kegiatan penelitian, (4) Tes hasil belajar, untuk mengukur hasil belajar siswa pada mata pelajaran penerapan rangkaian elektronika pada aspek kognitif dan aspek psikomotor digunakan metode tes. Tes yang digunakan dalam penelitian ini berupa pretest dan posttest yang terdiri dari 20 soal berbentuk pilihan ganda. Test dalam bentuk prestest bertujuan untuk mengetahui kemampuan awal siswa. Sementara Tes dalam bentuk posttest bertujuan untuk mengetahui kemampuan siswa dalam menguasai materi yang disampaikan setelah diberi perlakuan saat pembelajaran berlangsung.

Instrument pengumpulan data yang digunakan dalam penelitian ini adalah bentuk tes untuk aspek kognitif, dan lembar observasi untuk aspek psikomotorik yang bertujuan untuk menilai kemampuan siswa dalam pembelajaran penerapan rangkaian elektronika sebelum dan sesudah menerapkan software EWB dan Proteus.

Teknik analisis data yang digunakan dalam penelitian ini adalah teknik analisis data deskriptif kuantitatif. Analisis data deskriptif kuantitatif digunakan untuk menganalisis data kuantitatif seperti hasil tes belajar siswa. Keefektifan software EWB dan proteus dalam proses pebelajaran diuji dengan effect size (Saregar, A., Latifah, S., \& Sari, M, 2016) yang merupakan ukuran mengenai besarnya efek suatu variabel pada variabel lain. Variabel yang sering terkait biasanya veriabel independent dan variabel dependen. Effect size dapat dihitung dengan formulasi (Cohen, 1998) dan kemudian dijabarkan lebih rinci oleh (Hake, 2020).

$$
d=\frac{m_{A}-m_{B}}{\left[\left(s d_{A}^{2}+s d_{B}^{2}\right) / 2\right]^{1 / 2}}
$$

Keterangan:

d: effect size

$\mathrm{mA}$ : rata-rata gain kontrol

$\mathrm{mB}$ : rata-rata gain eksperimen

SdA: standar deviasi kontrol

SdB: standar deviasi eksperimen 
Kriteria besar kecilnya effect size dapat dilihat pada Tabel 3.

Tabel 3. Kriteria effect size

\begin{tabular}{cc}
\hline Effect Size & Kategori \\
\hline $\mathrm{d}<0,2$ & Kecil \\
$0,2<\mathrm{d}<0,8$ & Sedang \\
$\mathrm{d}>0,8$ & Tinggi \\
\hline
\end{tabular}

\section{HASIL DAN PEMBAHASAN}

Pretest dilakukan untuk mengetahui kemampuan awal siswa, dan posttest bertujuan untuk mengetahui kemampuan siswa setelah diberi perlakuan saat pembelajaran berlangsung. Berikut data hasil belajar siswa dalam aspek kognitif maupun psikomotor dapat dilihat pada Tabel 4.

Tabel 4. Perbedaan hasil belajar kelas kontrol dan kelas eksperimen

\begin{tabular}{lcccccc}
\hline & \multicolumn{3}{c}{ Kelas Kontrol } & \multicolumn{3}{c}{ Kelas Eksperimen } \\
\cline { 2 - 7 } Deskripsi & Pretest & Posttest & Psikomotor & Pretest & Posttest & Psikomotor \\
\hline \multirow{2}{*}{ Nilai Minimum } & & & & & & 75 \\
Nilai Maksimum & 20 & 50 & 60 & 30 & 80 & 90 \\
Mean & 85 & 90 & 85 & 70 & 50 & 92,06 \\
Standar Deviasi & 45,95 & 68,1 & 75,48 & 41,76 & 73,23 & 8,69 \\
\hline
\end{tabular}

Tabel 4 menunjukan perbedaan hasil belajar pada mata pelajaran penerapan rangkaian elektronika siswa antara kelas kontrol dan kelas eksperimen. Perbedaan tersebut dapat dilihat dari nilai rata-rata dimana rata-rata nilai kelas eksperimen lebih tinggi dibandingkan dengan kelas kontrol baik pada aspek kognitif maupun psikomotor. Perbedaan tersebut perlu diuji lebih lanjut, sebelum melakukan uji perbedaan rerata, perlu melakukan uji normalitas dan uji homogenitas.

\section{Uji Normalitas}

Uji normalitas dilakukan untuk mengetahui apakah data yang diperoleh berasal dari populasi yang normal atau tidak pada aspek kognitif dan aspek psikomotor. Uji normalitas data dilakukan dengan SPSS versi 21.0 menggunakan metode Kolmogorov-Smirnov dengan taraf signifikan 5\%. Adapun ketentuan uji normalitas ditunjukan pada Tabel 5.

Tabel 5. Ketentuan uji normalitas

\begin{tabular}{cc}
\hline Sig & Kriteria \\
\hline Sig $>0,05$ & Normal \\
Sig $<0,05$ & Tidak normal \\
\hline
\end{tabular}

Data yang digunakan untuk menguji normalitas data aspek kognitif adalah hasil belajar siswa kelas kontrol dan kelas eksperimen dalam bentuk pretest dan posttest. Hasil uji normalitas data aspek kognitif hasil pretest dan posttest dan psikomotor siswa kelas dapat dilihat pada Tabel 6 .

Tabel 6. Hasil ujinormalitas pretest, posttest dan psikomotor

\begin{tabular}{lcc}
\hline \multicolumn{1}{c}{ Kelompok Penelitian } & $\begin{array}{c}\text { Probabilitas } \\
\text { (Sig) }\end{array}$ & Keterangan \\
\hline Pretest kelas Kontrol & 0,000 & Data Tidak Normal \\
Posttest kelas Kontrol & 0,014 & Data Tidak Normal \\
Psikomotor kelas Kontrol & 0,000 & Data Tidak Normal \\
Pretest kelas Eksperimen & 0,000 & Data Tidak Normal \\
Posttest kelas Eksperimen & 0,000 & Data Tidak Normal \\
Psikomotor kelas Eksperimen & 0,002 & Data Tidak Normal \\
\hline
\end{tabular}


Tabel 6 menunjukan data pretest, posttest dan psikomotor siswa kelas kontrol dan kelas eksperimen memiliki nilai sig < 0,05, hal ini berarti bahwa data berdistribusi tidak normal.

\section{Uji Homogenitas}

Uji homogenitas data dilakukan untuk menentukan data yang diperoleh berasal dari populasi yang homogen atau tidak pada aspek kognitif dan aspek psikomotor. Uji homogenitas data dilakukan dengan SPSS versi 21.0 menggunakan uji levene dengan taraf signifikan 5\%. Adapun ketentuan uji homogenitas ditunjukan pada Tabel 7.
Tabel 7. Ketentuan uji homogenitas

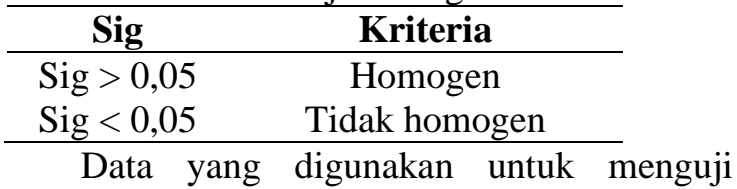
homogenitas data pada aspek kognitif adalah hasil belajar siswa kelas kontrol dan kelas eksperimen dalam bentuk pretest dan posttest. Hasil uji homogenitas data aspek kognitif hasil pretest, pretest dan psikomotor siswa dapat dilihat pada Tabel 8 .

Tabel 8. Hasil uji homogenitas pretest, posttetst dan psikomotor

\begin{tabular}{lcc}
\hline \multicolumn{1}{c}{ Kelompok Penelitian } & $\begin{array}{c}\text { Probabilitas } \\
\text { (Sig) }\end{array}$ & Keterangan \\
\hline Pretest kelas Kontrol & 0,516 & Homogen \\
Posttest kelas Kontrol & 0,157 & Homogen \\
Psikomotor kelas Kontrol & 0,084 & Homogen \\
Pretest kelas Eksperimen & 0,516 & Homogen \\
Posttest kelas Eksperimen & 0,157 & Homogen \\
Psikomotor kelas Eksperimen & 0,084 & Homogen \\
\hline
\end{tabular}

Tabel 8 menunjukan data pretest, posttest dan psikomotor siswa kelas kontrol dan kelas eksperimen memiliki nilai sig $>0,05$, hal ini berarti bahwa data bersifat homogen.

\section{Uji Hipotesis}

Pengujian hipotesis dilakukan setelah mengetahui data hasil penilaian siswa yang didapat baik pada aspek kognitif maupun psikomotor yang tidak normal dan bersifat homogen. Pengujian hipotesis yang digunakan adalah uji non parametrik yang dilakukan dengan menggunakan uji Mann Withney (UjiU) dengan SPSS versi 21.0.

\section{a. Hipotesis pertama}

Pengujian hipotesis pertama ini adalah untuk mengetahui perbedaan hasil belajar siswa pada aspek kognitif antara kelas kontrol dan kelas eksperimen. Dengan ketentuan uji pada Tabel 9.

Tabel 9. Ketentuan uji hipotesis pertama

\begin{tabular}{cl}
\hline Uji hipotesis & \multicolumn{1}{c}{ Keterangan } \\
\hline $\mathrm{H}_{0}$ & $\begin{array}{l}\text { Tidak ada Perbedaan hasil belajar siswa yang signifikan aspek kognitif antara hasil } \\
\text { belajar siswa dengan software EWB dan software Proteus }\end{array}$ \\
& $\begin{array}{l}\text { Ada Perbedaan hasil belajar siswa yang signifikan aspek kognitif antara } \\
\text { hasil belajar siswa dengan software EWB dan software Proteus }\end{array}$ \\
\hline
\end{tabular}

Hasil uji hipotesis pertama pada penelitian dapat dilihat pada tabel 10 .
Tabel 10. Hasil uji hipotesis pertama

\begin{tabular}{ll}
\hline & Hasil Belajar Siswa \\
\hline Mann-Whitney $U$ & 76500 \\
Wilcoxon $W$ & 671,500 \\
$Z$ & $-6,397$ \\
Asymp. Sig. (2-tailed) &, 000 \\
\hline
\end{tabular}


Berdasarkan hasil pengujian hipotesis dengan SPSS versi 21.0 menggunakan Mann Withney (Uji-U) diperoleh hasil sig. (2-tailed) sebesar 0,000. Jika nilai sig. (2-tailed) kurang dari alpha $0,05,0,00<0,05$, maka hipotesis nol ditolak dan hipotesis satu diterima.

\section{b. Hipotesis kedua}

Pengujian hipotesis kedua ini adalah untuk mengetahui perbedaan hasil belajar siswa pada aspek psikomotor antara kelas kontrol dan kelas eksperimen. Dengan ketentuan uji terdapat pada Tabel 11.

Tabel 11. Ketentuan uji hipotesis kedua

\begin{tabular}{cl}
\hline Uji hipotesis & \multicolumn{1}{c}{ Keterangan } \\
\hline $\mathrm{H}_{0}$ & $\begin{array}{l}\text { Tidak ada Perbedaan hasil belajar siswa yang signifikan aspek Psikomotor antara } \\
\text { hasil belajar siswa dengan software EWB dan software Proteus }\end{array}$ \\
& $\begin{array}{l}\text { Ada Perbedaan hasil belajar siswa yang signifikan aspek Psikomotor antara hasil } \\
\text { belajar siswa dengan software EWB dan software Proteus }\end{array}$ \\
\hline
\end{tabular}

Hasil uji hipotesis kedua pada penelitian dapat dilihat pada Tabel 12 .

Tabel 12. Hasil Uji Hipotesis Kedua

\begin{tabular}{ll}
\hline & Hasil Belajar Siswa \\
\hline Mann-Whitney $U$ & 276,000 \\
Wilcoxon $W$ & 871,500 \\
$Z$ & $-3,948$ \\
Asymp. Sig. (2-tailed) &, 000 \\
\hline
\end{tabular}

Berdasarkan hasil pengujian hipotesis dengan SPSS versi 21.0 menggunakan Mann Withney U diperoleh hasil sig. (2-tailed) sebesar
0,000. Jika nilai sig. (2-tailed) kurang dari alpha $0,05,0,00<0,05$, maka hipotesis nol ditolak dan hipotesis satu diterima.

\section{c. Hipotesis Ketiga}

Pengujian hipotesis ketiga ini adalah untuk mengetahui efektivitas software EWB dan software Proteus terhadap hasil belajar siswa mata pelajaran penerapan rangkaian elektronika. Dengan ketentuan uji terdapat pada Tabel 13. Hasil uji hipotesis ketiga pada penelitian dapat dilihat pada Tabel 14 .

Tabel 13. Ketentuan uji hipotesis ketiga

\begin{tabular}{cl}
\hline Uji hipotesis & \multicolumn{1}{c}{ Keterangan } \\
\hline $\mathrm{H}_{0}$ & $\begin{array}{l}\text { Tidak ada Efektivitas software EWB dan software Proteus terhadap hasil belajar } \\
\text { siswa mata pelajaran penerapan rangkaian elektronika }\end{array}$ \\
$\mathrm{H}_{1}$ & $\begin{array}{l}\text { Ada Efektivitas software EWB dan software Proteus terhadap hasil belajar siswa } \\
\text { mata pelajaran penerapan rangkaian elektronika }\end{array}$ \\
\hline
\end{tabular}

Tabel 14. Hasil Effect Size

\begin{tabular}{lcccc}
\hline \multicolumn{1}{c}{ Kelas } & $\begin{array}{c}\text { Rata-rata Gain } \\
(\mathrm{M})\end{array}$ & Standar Deviasi (sd) & $\begin{array}{c}\text { Effect Size } \\
(\mathrm{d})\end{array}$ & Keterangan \\
\hline Kontrol & 0,3357 & 0,23068 & 0,93 & Tinggi \\
Eksperimen & 0,5242 & 0,17038 & 0,93 & \\
\hline
\end{tabular}

Hipotesis ketiga dalam penelitian ini adalah untuk mengetahui efektivitas software EWB dan proteus menggunakan effect size. Effect size digunakan sebagai ukuran mengenai tingkat keberhasilan dakam penelitian (Huck, 2012). Hasil 0,93 diperoleh software proteus yang berarti bahwa software proteus memiliki efektivitas yang tinggi untuk diterapkan dalam kegiatan pembelajaran karena memberikan perbedaan hasil belajar yang signifikan baik pada aspek kognitif maupun aspek psikomotor.

\section{SIMPULAN}

Hasil belajar siswa pada aspek kognitif yang diterapkan software EWB memiliki nilai rata-rata sebesar 68,1. Rerata nilai tersebut menunjukkan adanya peningkatan yang signifikan dari sebelum diberi perlakuan yang dimana nilai rata-rata yang didapat sebesar 
45,95. Sedangkan aspek psikomotor memiliki nilai rata-rata sebesar 75,48 . Hasil pengujian hipotesis dengan Mann Withney (Uji U) menggunakan SPSS versi 21.0 diperoleh hasil sig. (2-tailed) sebesar 0,000. Jika nilai sig. (2tailed) kurang dari alpha 0,05, dengan demikian hasil hipotesis menunjukkan bahwa ada perbedaan hasil belajar siswa yang signifikan dalam aspek kognitif dan aspek psikomotor antara pembelajaran menggunakan software EWB.

Hasil belajar siswa pada aspek kognitif yang diterapkan software proteus memiliki ratarata sebesar 73,23. Nilai rerataan tersebut mengalami peningkatan tetapi tidak signifikan dari sebelum diberi perlakuan yang dimana nilai rata-rata yang didapat sebesar 41,76. Sementara pada aspek psikomotor mendapat nilai rata-rata sebesar 82,06. Berdasarkan hasil pengujian hipotesis dengan Mann Withney (Uji U) menggunakan SPSS versi 21.0 diperoleh hasil sig. (2-tailed) sebesar 0,000. Jika nilai sig. (2tailed) kurang dari alpha 0,05 , sehingga hipotesis menunjukkan ada perbedaan hasil belajar siswa yang signifikan dalam aspek kognitif dan aspek psikomotor antara pembelajaran siswa menggunakan software EWB dan Proteus.

Hasil belajar siswa yang diberi perlakuan berupa software proteus selama proses pembelajaran berlangsung mendapat nilai ratarata sebesar 73,23 dan rata-rata untuk nilai psikomotor sebesar 82,06 sedangkan hasil belajar siswa yang diberi perlakuan software EWB selama proses pembelajaran memiliki rerata nilai sebesar 68,1 dan rata-rata nilai psikomotor sebesar 75,48. Hal tersebut terlihat bahwa perlakuan dengan software proteus memberikan hasil belajar siswa yang lebih tinggi baik pada ranah kognitif maupun psikomotor mata pelajaran penerapan rangkaian elektronika dibandingkan dengan pemberian perlakuan berupa software EWB selama proses pembelajaran berlangsung.

Hasil ni lai effect size yang didapat sebesar 0,93, menunjukkan bahwa software proteus sangat efektif untuk diterapkan dalam kegiatan pembelajaran mata pelajaran penerapan rangkaian elektronika.

\section{DAFTAR RUJUKAN}

Anhar, K., \& Syariffudien. (2013). Penggunaan media pembelajaran berbasis ISIS
Proteus Untuk Meningkatkan Hasil Belajar Siswa Kelas X Pada Standar Kompetensi Menerapkan dasar-dasar Elektronika. Jurnal Pendidikan Teknik Elektro, 575-582.

Arikunto, S. (2013). Dasar-dasar Evaluasi Pendidikan. Jakarta: PT. Bumi Aksara.

Arsyad, A. (2015). Media Pembelajaran Edisi Revisi. Jakarta: Rajawali Pers.

E.K, L., \& R.M, Y. (2015). Penelitian Pendidikan Matematika. Bandung: PT. Refika Aditama.

Hake, R. R. (2002, August).Relationship of invidual student normalized learning gains in mechanics with gender, highschool on mathematics and spatial visualization. In submitted to the Physics Education Research Conference (Boise, ID))

Haryano, A., Raharjo, R., Rahardjito, \& S, A. S. (2010). Media Pendidikan. Jakarta: PT. Raja Grafindo Persada.

Mariyanti, D. (2012). Peningkatan motivasi dan pemahaman siswa SMKN 5 Banjarmasin terhadap dasar teknik digital dengan media simulasi electronic workbench . Jurnal Pendidikan Vokasi, 127-142.

Muhidin, S., \& Abdurrahman, M. (2007). Analisis Korelasi, Regresi dan Jalur dalam Penelitian. Bandung: C. Pustaka Setia.

Mukminin, M., \& Santosa, A. B. (2016). Pengaruh Media Pembelajaran Software Proteus Pada Mata Pelajaran Penerapan Rangkaian Elektronika Terhadap Hasil Belajar Siswa Kelas XI Teknik Audio Video di SMK Negeri 3 Surabaya. Jurnal Pendidikan Teknik Elektro, 147-154.

Nani, K., \& Kusumah, Y. (2015). The Effectiveness Offict-Assited Project Based Learning In Enchangcing Student Stastical Communication 
Ability. International Journal of Education and Research , 190-191.

Nurhayati, \& Rifai, A. (2016). Media Pembelajaran Berbasis Komputer Pada Mata Pelajaran Rangkaian Elektronika Untuk Siswa Kelas XI Teknik Elektronika Industri di SMK Negeri 2 Bojonegoro. Jurnal Pendidika Teknik Elektro, 453-461.

Prasetyo B, \& Jannah, L. (2008). Metode Penelitian Kuantitatif. Jakarta: PT. Raja Grafindo Persada.

Purwadi, S., \& Joko. (2013). Pengaruh Model Pembelajaran Aktif Tipe Active Observation and Feedback dan Model Pembelajaran Langsung Terhadap Hasil Belajar Siswa Pada Standar Kompetensi Memahami Pengukuran Komponen Elektronika di SMK Negeri 2 Surabaya . Jurnal Penelitian Pendidikan Teknik Elektro, 123-130.

Purwanto. (2014). Evaluasi Hasil Belajar. Yogyakarta: Pustaka Belajar.

Sanjaya, W. (2012). Media Komunikasi Pembelajaran. Jakarta: Kencana.

Saregar, A., Latifah, S., \& Sari, M. (2016). Efektivitas Model Pembelajaran CUPS: Dampak Terhadap Kemampuan Berpikir Tingkat Tinggi Peserta Didik Madrasah Aliyah Mathla'ul Anwar Gisting Lampung. Jurnal Ilmiah Pendidikan Fisika Al-Biruni, 233-243.

Subana, M. R., \& Sudrajat. (2015). Statistik Pendidikan. Bandung : CV. Pustaka Setia.

Sudaryono. (2017). Metodologi Penelitian. Jakarta: PT. Raja Grafindo Persada.

Sudjana, N. (2017). Penilaian Hasil Proses Belajar Mengajar. Bandung: PT. Remaja Rosdakarya.

Sugiyono. (2015). Metode Penelitian Pendidikan. Bandung: Alfabeta.
Susanto , A. (2013). Teori Belajar dan Pembelajaran. Jakarta: Kencana. 